\title{
DEMOGRAPHIC ANALYSIS OF THE RETAIL BUSINESS HYPERMARKET IN INDONESIA
}

\author{
Benny Bernadus*)1, M. Syamsul Maarif *), Setiadi Djohar**), Arif Imam Suroso*) \\ ${ }^{*}$ School of Business, IPB University \\ Jl. Pajajaran, Bogor 16151, Indonesia \\ ${ }^{* *}$ PPM School of Management \\ Jl. Menteng Raya 9-19, Menteng, Jakarta 10340, Indonesia
}

\begin{abstract}
The hypermarket business in Indonesia has been declining for 5 years. This study aims to analyze the condition of hypermarket retail in Indonesia through demographic analysis. This descriptive study uses research measuring instrument using a Likert scale questionnaire $1-5$, the number of samples is 660 . The new concept of retail organizational performance, not only involves marketing aspects: service quality, customer trust, and customer loyalty but also includes organizational capability variables as variables that affect retail business performance; Hypermarket studies cover a national scope in contrast to other retail studies which are only locally specific. The results showed that the characteristics of hypermarket customers in Indonesia are; The majority of women are married, have a bachelor/undergraduate education, age range 46-55 years, live in the Jabodetabek area, work as private employees, monthly expenditures are Rp10,000,100Rp12,500,000, the number of visits in a year to hypermarkets is 7-10 times on average and 11-14 times, and hypermart stores are the most visited. Hypermarket conditions: service quality and organizational capabilities are in the criteria of both low borderline to moderate, customer trust, customer loyalty, and business performance in moderate conditions.
\end{abstract}

Keywords: hypermarket business, service quality, customer trust, customer loyalty, organizational performance

\begin{abstract}
Abstrak: Bisnis hypermarket di Indonesia mengalami penurunan selama 5 tahun terakhir. Penelitian ini bertujuan menganalisis kondisi ritel hypermarket di Indonesia melalui analisis demografi. Penelitian deskriptif ini menggunakan alat ukur berupa angket skala Likert 1-5, dengan jumlah sample 660. Konsep baru kinerja organisasi ritel, tidak hanya melibatkan aspek pemasaran: kualitas layanan, kepercayaan pelanggan, dan loyalitas pelanggan tetapi juga memasukkan variabel kapabilitas organisasi sebagai variabel yang memengaruhi kinerja bisnis ritel. Studi tentang hypermarket mencakup ruang lingkup nasional berbeda dengan studi ritel lain yang hanya spesifik secara lokal. Hasil penelitian menunjukkan bahwa karakteristik pelanggan hypermarket di Indonesia adalah; Mayoritas perempuan, sudah menikah, berpendidikan sarjana/sarjana, rentang usia 46-55 tahun, berdomisili di wilayah Jabodetabek, bekerja sebagai pegawai swasta, pengeluaran perbulan Rp10.000.100-Rp12.500.000, jumlah kunjungan dalam setahun ke hypermarket rata-rata 7-10 kali dan 11-14 kali dan hypermarket terbanyak dikunjungi adalah toko hypermart. Kondisi hypermarket: kualitas pelayanan dan kapabilitas organisasi berada pada kriteria baik rendah borderline ke moderat, kepercayaan pelanggan, loyalitas pelanggan dan kinerja bisnis dalam kondisi moderat.
\end{abstract}

Kata kunci: bisnis hypermarket, kualitas layanan, kepercayaan pelanggan, loyalitas pelanggan, kinerja organisasi

\footnotetext{
${ }^{1}$ Corresponding author:

Email: benny.madrais@gmail.com
} 


\section{INTRODUCTION}

The performance of the hypermarket retail business has experienced a very significant decline in the last 5 years and has shown negative growth. Hero Supermarket Tbk. as the owner of a Giant hypermarket, for the last 7 years to 2019 , the best growth was in 2015 , namely $16.05 \%$. Since 2016 it has decreased until 2019 has grown $-5.42 \%$. The largest current year profit was experienced in 2013 amounting to 671 billion rupiah, after that it never reached that figure, even in 2018 it experienced the biggest loss of $-1,250$ trillion rupiah. 2017 experienced a loss of -191 billion rupiah. in 2019 it posted a profit for the year of 70 billion rupiah, this profit is not solely from sales because sales are still experiencing negative growth, but with various efficiencies such as closing outlets, reducing employees, reducing costs and so on (Annual Report PT. Hero Supermarket Tbk. 20152019). Matahari Putra Prima Tbk also experienced the condition of decreasing income and losses. as the owner of Hypermart, in 2014 revenue grew 14.07\% with sales of 13.59 trillion rupiah, profit for the year was 554 billion. In 2019, growth of $-19.05 \%$, revenue of 8.65 trillion and losses of -553 billion. 2018 experienced a loss of -899 billion rupiah. MPPA's performance in 2019 compared to 2019 experienced a decrease in revenue of $-36 \%$, decreased in profit for the year by $-200 \%$. (Annual Report PT. Matahari Putra Prima Tbk. 2015-2019).

Customercomplaints submitted through shortinterviews and online which have been summarized during 2016 to 2019 (Kompas, detikNews, mediakonsumen.com) write and convey that Hypermarkets are currently experiencing several conditions, including: Service quality: products sold found to be inappropriate, out of date, rotten, the color has changed, and the packaging is damaged, disrespectful attitude, lack of respect, forgetting to say thank you, ignoring customers, service impressed. The sales area is not clean, dirty, wet, the cold room does not operate, the cardboard smells fishy, it is long because the cashier is slow and takes a long time to serve; Organizational Capability: also conveyed if the supplies of goods needed are often not available. incorrectly entered the price or when the refund (refund), there is a double payment. The use of sensors or scanners that are not precise enough to cause differences in the goods being scanned/scanned with the items purchased; Customer trust: customers feel company staff are dishonest, for example payment for goods is not included in proof of payment and prices are not as promised, promo items are not as promised, apologies are made insincerely; Customer loyalty: The price is more expensive than the price shown on the goods shelf/display. Customers look for other stores, long queues so they buy at other stores such as minimarkets. Carmichael (2016) defines demography as the study of the human population.

Demographic analysis includes demographic characteristics; age, gender, marital status, occupation, etc.) as well as demographic events; birth, death, marriage, migration, etc.). This reinforces the concept of Siegel and Swanson (2004) which states demography as a scientific study of the human population including size, distribution, composition and the factors that influence its changes, focusing on 5 aspects of human population: (1) size, (2) distribution), (3) composition, (4) dynamic population and (5) socioeconomic (socioeconomic) determination and the consequences of population change. Murdock et al. (2006) defines demography as the study of the size, distribution, composition of the population; and the process of determining births, deaths and migration and their effects. Demography as a scientific depiction and forecasting of the characteristics of the human population, as well as its impact on economic, socio-political and cultural characteristics. The study of this population involves interdisciplinary studies from various sciences such as sociology, anthropology, psychology, economics, geography, history, epidemiology and medicine to make the study of this population interesting and through the approaches of other sciences to be complementary.

Reviewing the condition of the retail business is always related to the performance of the retail business itself or the performance of the retail business organization. Armstrong and Baron (2009) define performance as something that has been achieved by a person or organization and as an accumulation of behaviour, company performance is divided into three, namely marketing performance, operational performance and service performance. The performance itself is influenced by various factors such as service quality, organizational capabilities, customer trust and customer loyalty. Organizational capability is an organization's ability to process its resources to be able to answer existing business challenges. Collis (1994) categorizes organizational capabilities into three categories, namely static capabilities, dynamic capabilities, and creative capabilities. Service Quality by Zeithaml et al. (2002) is divided into 5 dimensions; Reliability, Tangibles, 
Responsiveness, Assurance, Empathy. Customer trust is the willingness of customers to tie themselves with the company to business partners as expressed (Kotler and Keller, 2016). Mayer et al. (2007) stated that there are three factors that shape a person's trust in a company's brand: sincerity/kindness (benevolence), ability (ability) and integrity (integrity). Griffin et al. (2014) explain customer loyalty as a customer commitment to repurchasing, repeating a selected product or service as a consistent attitude in the future, referring to others and being immune to the pull of competitors.

Previous research regarding organizational capabilities, service quality, customer trust, customer loyalty affects performance has been going on for a long time, such as; Rajapathirana and Hui (2018), innovative capabilities have a positive effect on the impact of improving company performance, Babelyte et al. (2017) has a positive effect of dynamic capabilities on performance. Mehta and Tariq (2020) The competitive environment of supermarkets requires customer loyalty. Customer trust is a determining factor for the continuity of buyer relationships (Rampl et al. 2012). Alkhurshan et al. (2020) The positive effects of trust, service quality, pleasure, intimacy and satisfaction have a positive and statistically significant impact on customer loyalty. Kennedy et al. (2019) states that positive results throughout the organization are carried out by monitoring service standards, this shows the positive impact of services on performance. This research is about organizational performance, which so far has had a lot of emphasis on marketing aspects: service quality, customer trust and customer loyalty, but in this study provides a new concept by including the organizational capability variable as a variable that affects the performance of the retail business, and this research also has the character of national, compared to previous studies that were local or specific in nature.

Current retail research in Indonesia focuses more on certain outlets and in certain locations so that it is still local and not at the national scale of Indonesia (Sunanto 2013) in West Java; Widyastuti (2018) in Jakarta; Puspaningrum (2018); Sutanto and Djati in East Java; Mamuaya and Pandowo (2018) in Manado; Cules et al. (2018) in Bali, and various studies that focus on specific areas. The literature on business performance and the capabilities of hypermarket format retail organizations in Indonesia and on a national scale is still relatively limited. Therefore, this research complements previous research. Approaches through demographic analysis through the Likert scale will add insights to the current condition of hypermarket retail.

The aim of this research is to analysis the demographic characteristics of hypermarket format customers in Indonesia today and to describe the condition of the hypermarket based on the variables of service quality, organizational capabilities, customer trust, customer loyalty and hypermarket performance in Indonesia.

\section{METHODS}

This analysis research was conducted at the go public hypermarketretailcompanyinIndonesia. Data collection from January to July 2020 throughout Indonesia. This study uses primary and secondary data. Primary data were obtained from questionnaires both directly and online, through social media, direct observation, and interviews. Secondary data were obtained and processed based on company financial reports (annual reports), websites, newspapers and magazines. The research was conducted using non-probability sampling techniques with purposive sampling method, which is a sampling with certain considerations. The determination of the number of samples for one indicator for 10 observers is the same as Westland (2019) using the "rules of ten". In this study, there are 5 variables and 64 indicators, so with the principle of 1 indicator for 10 samples, the minimum sample is 640 samples, in this study using 660 samples. Demographic Analysis with data calculation techniques using a Likert scale of 1 to 5 to calculate consumer opinions from 660 samples, used to describe the current retail condition.

The framework of this research is as follows; The problem of retail performance which is currently decreasing, it is necessary to describe and analyze the demographic conditions of hypermarket customers in Indonesia, so that retail companies can produce goods and services as desired and in accordance with the characteristics of the Indonesian population. The demographic factors analyzed are; Gender, marital status, age, education, domicile, occupation, monthly expenses, average number of visits to hypermarkets in one year, hypermarkets are the most visited. As well as analyzing the research variables: service quality, organizational capability, customer trust and customer loyalty from the 8 demographic areas above. The 
results of the analysis and description of the conditions of the variables in terms of demographics will provide input for retail stakeholders to improve hypermarket performance. Further illustrated in Figure 1 regarding the research framework.

\section{RESULTS}

\section{Distribution of Correspondent Demographic Data}

This study processed data of 660 questionnaires, based on information from the questionnaire obtained information on grouping demographic factors according to gender, education, city of residence, marital status, occupation, age, monthly expenses, visits to hypermarkets in a year and hypermarkets visited.

Based on Figure 2, classification of respondents based on identity can be described as follows. Female gender was more dominant as many as 388 respondents $(58.79 \%)$ of the population, while 272 respondents (41.21\%) were men. Women need more attention from retailers, because they know more about household needs or daily family needs; The majority of respondents were married as many as 475 people (71.97\%), 155 people (23.48\%) were unmarried and 30 people (4.55\%) were widows. The needs of those who are married are of course more, and they also buy more needs for all family members, so the needs of those who are married need more attention.

The ages of the respondents were 46-55 years; 214 people (32.42\%), ranked second 26-35 years; 170 people (25.76\%), then each $36-45$ years; 129 (19.55\%), aged $56-65$ years 83 people (12.58\%), 53 people aged $16-25$ years $(8.03 \%)$ and 11 people over 65 years $(1.67 \%)$. According to the Ministry of Health of the Republic of Indonesia, in 2009 the age range of 46-55 years was early age, currently it is economically stable and the position is stable, it is also said that the transition period to old age, the decrease in the number of hormones in the body and the function of organs is also decreasing. Therefore it is necessary to pay attention to food or healthy food to maintain health starting to get more attention at this age.

Most respondents were bachelor degree with 348 people (52.73\%), Second Place Master degree 149 people (22.58\%), Senior High School 74 people (11.21\%), Diploma 68 people $(10.30 \%)$. and Doctor as many as 21 people $(3.18 \%)$. The majority of education is bachelor degree will have more rational considerations, in this case the hypermarket in selling products and services must receive rational consideration and good knowledge for its customers.

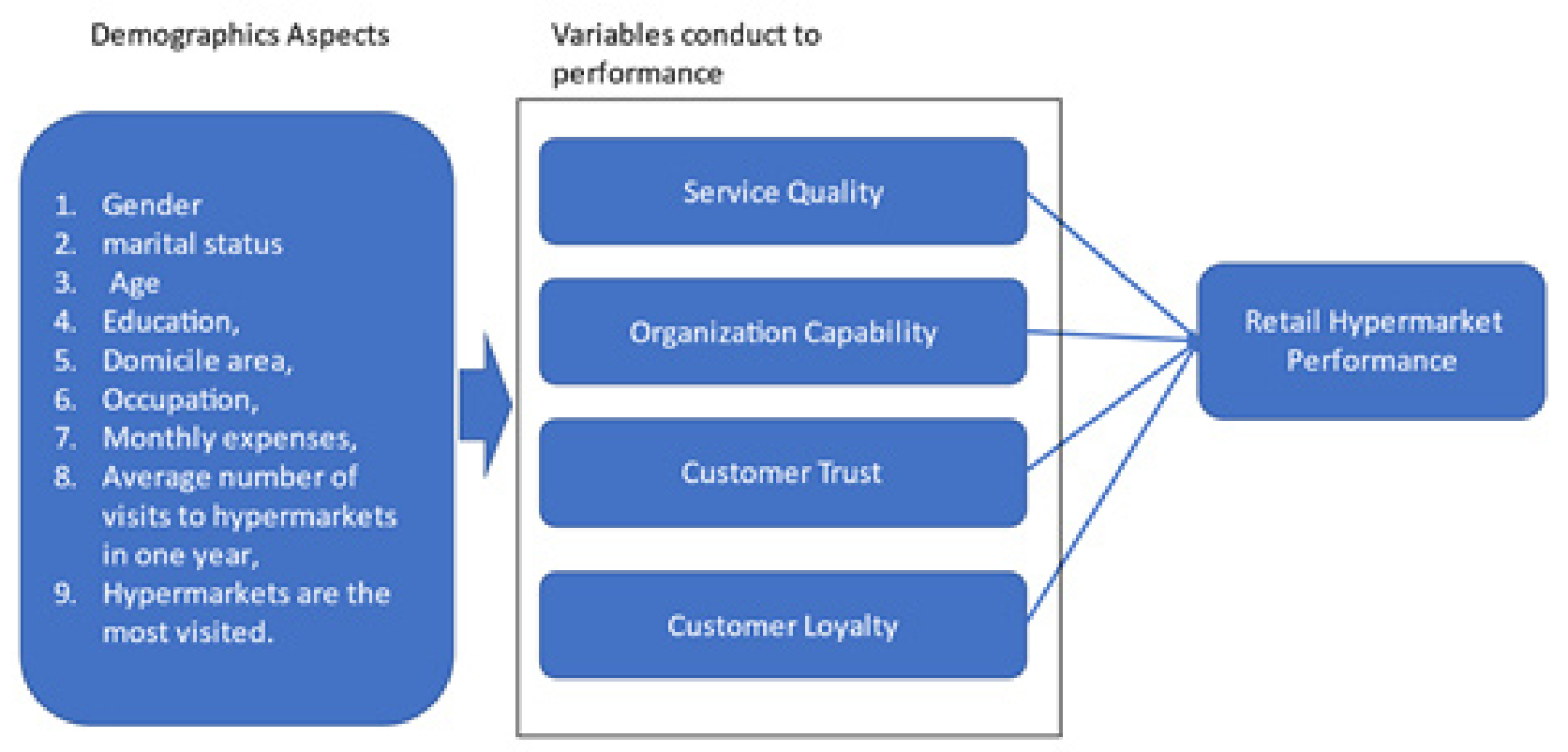

Figure 1. Research framework 

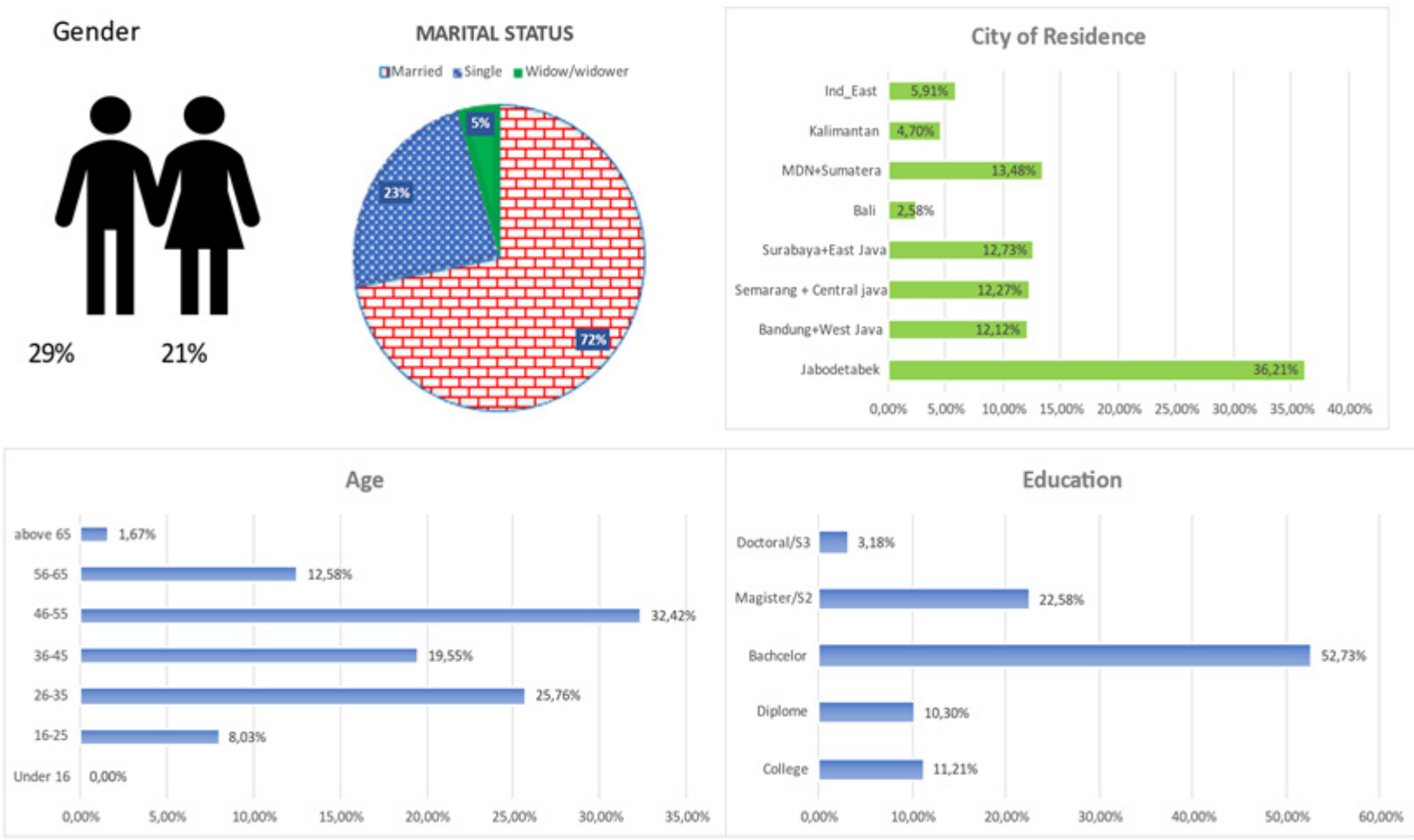

Figure 2. Classification of respondents based on identity

The largest respondents were in the Greater Jakarta area (Jabodetabek; Jakarta, Bogor, Depok and Bekasi) with 239 respondents (36.21\%), Medan and Sumatra in second place with 89 people (13.48\%), Surabaya and East Java with 84 people (12.73\%), Semarang, Central Java and Yogyakarta 81 people (12.27\%), Bandung and West Java 80 people (12.12\%), East Indonesia 39 people (5.91\%), Kalimantan 31 people ( $4.7 \%)$ and Bali 17 people $(2.58 \%)$. Economic researcher at the Institute for Development of Economics and Finance (Indef) Bhima Yudhistira said $70 \%$ of national money movements occurred in Jakarta $(15 / 3 / 2020)$. The largest hypermarket customer population is still in the Jabodetabek area, so Hypermarket managers must try to seize opportunities from the circulation of national money, with such a large turnover, Jabodetabek still has a big opportunity.

Based on Figure 3, Respondent Classification Data based on Activity can be described as follows. Private employees rank first as many as $272(41.21 \%)$, then second place with entrepreneurs as many as 137 people (20.76\%), government employees and BUMN (StateOwned Enterprises) 63 people $(9.55 \%)$ the same as mothers Households are 63 people $(9.55 \%)$, Not working and retired 37 people (5.61\%), Professionals (doctors, psychologists, legal experts, notaries etc.) as many as 34 people (5.15\%), Students / Students
21 people (3.18)\%), 17 teachers / lecturers $(2.58 \%)$, 8 Legislatives (1.21\%), 5 Military/Police $(0.76 \%)$ and 3 spiritualists $(0.45 \%)$ This employee job requires the company to be able to find goods and services for private employees and entrepreneurs.

Respondents with a monthly expenditure range of Rp10,000,100-Rp12,500,000 as many as 126 people $(19.09 \%)$, followed by the second winner Rp5,000,100-Rp7,500,000 as much as $113(17.12 \%)$, the expenditure of more than Rp20 million as many as 100 people (15.15\%), Rp15,000,100-Rp17,500,000 as many as 92 people (13.94\%), spending Rp12,500,100 $-\mathrm{Rp} 15,000,000$ as many as 87 people $(13.18 \%)$, spending $\mathrm{Rp} 7,500,100-\mathrm{Rp} 10,000,000$ as many as 58 people (8.79\%), Expenditures Rp17,500,100 Rp20,000,000 as many as 55 people $(8.33 \%)$, spending Rp2,500,000-Rp5,000,000 for 27 people (4.09\%) and less than Rp2,500,000 only 2 people $(0.30 \%)$; The biggest shopping frequency at hypermarkets is $7-10$ times/year as many as 157 people $(23.79 \%)$ and $11-$ 14 times/year as many as 157 people $(23.79 \%$, More than 18 times/year 129 people (19.55) )\%), while spending $15-18$ times/year was 51 people $(7.73 \%)$ and lastly less than 3 times/year were 26 people (3.94\%). This condition the company must provide goods or merchandise for the middle class. 


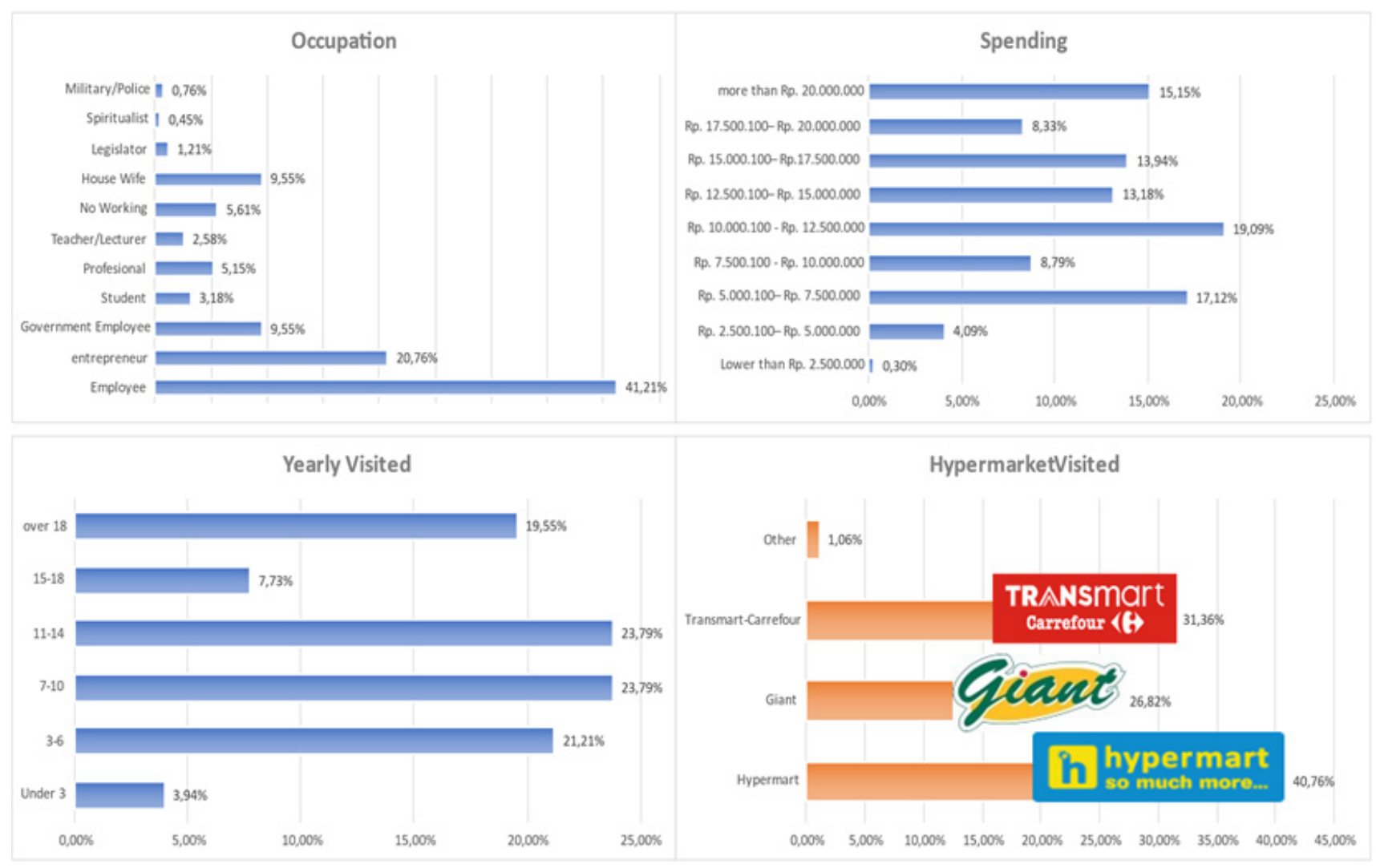

Figure 3. Respondent classification data based on activity

Most customers shop at Hypermart stores as many as 269 people $(40.76 \%)$, the second place is Giant Shops 177 people $(26.82 \%)$, Transmart-Carrefour stores as many as 207 people $(31.36 \%)$, the rest are other stores as many as 7 people $(1,06 \%)$. Othes companies other than hypermart must be more active to promote or provide more attractiveness so that more customers come to their stores.

Based on the description of the data that has been presented, it is concluded that the characteristics of Indonesian hypermarket customers are; The majority of sex is female, marital status is married, education level is bachelor degree, age range 46-55 years, lives in the Jabodetabek area, works as a private employee, monthly expenditure is $\mathrm{Rp} 10,000,100$ - Rp12,500,000, visited the hypermarket an average of 7-10 times and 11-14 times a year and the most visited hypermarkets were Hypermart stores. This has an impact on the selection of products sold in hypermarkets that prefer products that are spent by women such as daily necessities, household necessities, beauty and women's clothing. Products and quality are also intended for consumption of the upper middle class and for adults. Marketing and service more rational makes sense, because the majority of consumers undergraduate education. Jabodetabek is the center of attention because $60 \%$ of the money circulating in Indonesia is focused on Jabodetabek, so hypermarkets must develop in the Jabodetabek area.

\section{Analysis of hypermarket conditions in Indonesia}

Determination of Criteria

Based on the questionnaire collected 660 pieces and the number of items for each variable. The Likert scale calculation is used to describe the condition of hypermarkets in Indonesia with the following steps. Based on the collected questionnaires, the Likert scale calculation is used to describe the condition of hypermarkets in Indonesia with the following steps; calculate the minimum value, maximum value and the interval for each variable, creation of a range of criteria for each criterion (Table 1). The final results for each variable in the criteria are as follows Table 2. Calculate the total value for each variable and determine the variable criteria;

$$
\text { Total Variable Value }=\sum_{\mathrm{i}=1}^{5}(\mathrm{xi} \times \mathrm{i})
$$

Note: i $(1,2,3,4,5)$; xi (Number of respondents choosing the value i). 
The description of the results of the variables and demographic

The presentation of the results for each variable associated with demography is presented in Figure 4 and Figure 5. The customer perceived service quality to be in good condition (71.28\%). The dimensions of direct physical evidence are perceived as good (78.08\%), good reliability ( $73.42 \%)$ and good assurance $(70.33 \%)$, while responsiveness is moderate $(66.97 \%)$ and empathy is moderate $(67.60 \%)$.
Table I. Percentage range criteria

\begin{tabular}{ccl}
\hline Min & Max & Criteria \\
\hline $20.00 \%$ & $35.99 \%$ & Very Bad \\
$36.00 \%$ & $51.99 \%$ & Bad \\
$52.00 \%$ & $67.99 \%$ & Moderate/Fair \\
$68.00 \%$ & $83.99 \%$ & Good \\
$84.00 \%$ & $100 \%$ & Very Good \\
\hline
\end{tabular}

Table 2. Variable criteria calculation results

\begin{tabular}{lccl}
\hline Variable & Total Score & $\%$ & Criteria \\
\hline Service Quality & 47.045 & $71.28 \%$ & Good borderline to moderate \\
Capability Organization & 35.147 & $71.00 \%$ & Good borderline to moderate \\
Customer Trust & 26.921 & $67.98 \%$ & Moderate \\
Customer Loyalty & 14.767 & $63.93 \%$ & Moderate \\
Organization Performance & 28.764 & $67.05 \%$ & Moderate \\
\hline
\end{tabular}
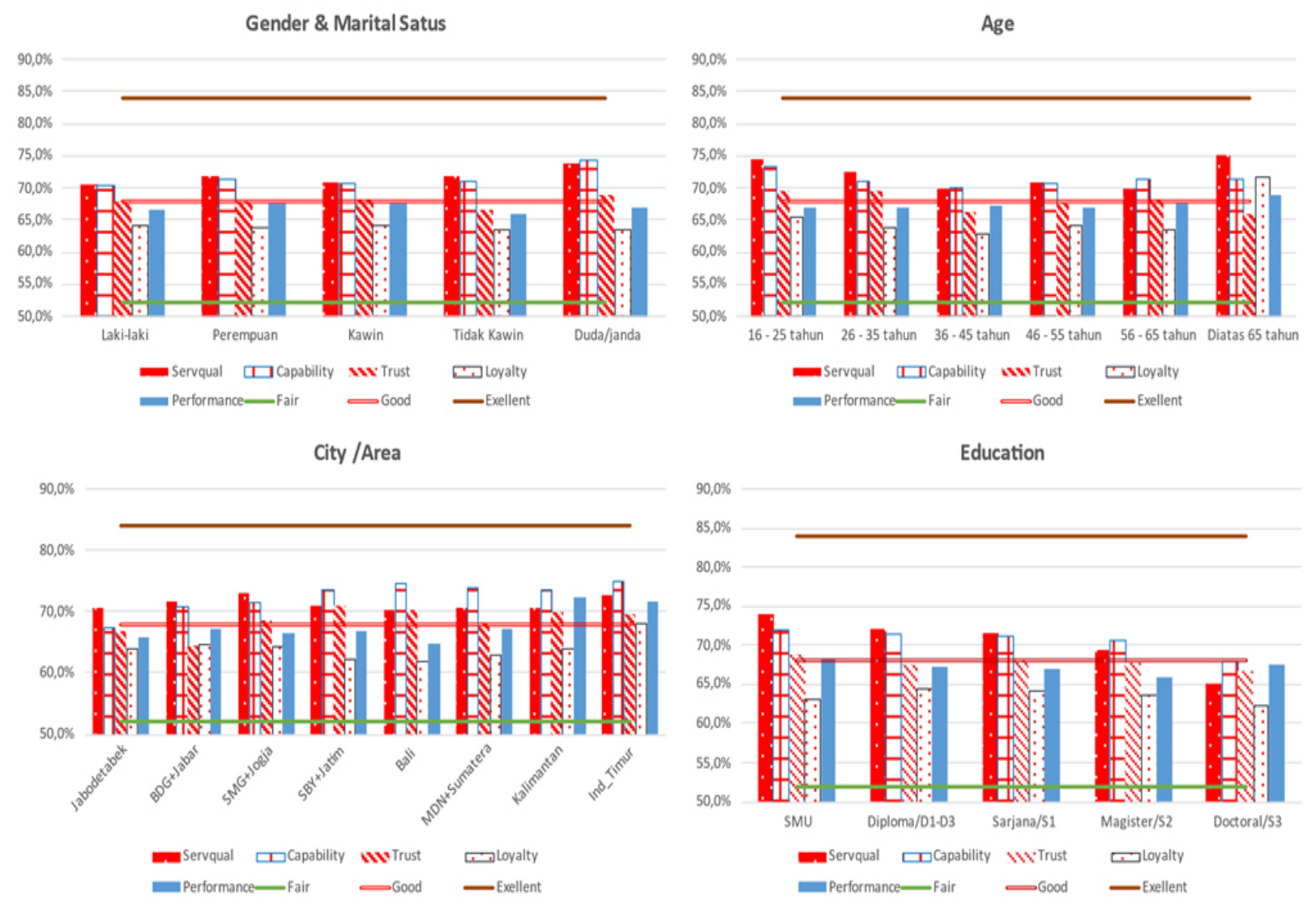

Figure 4. Variable and identity respondent 

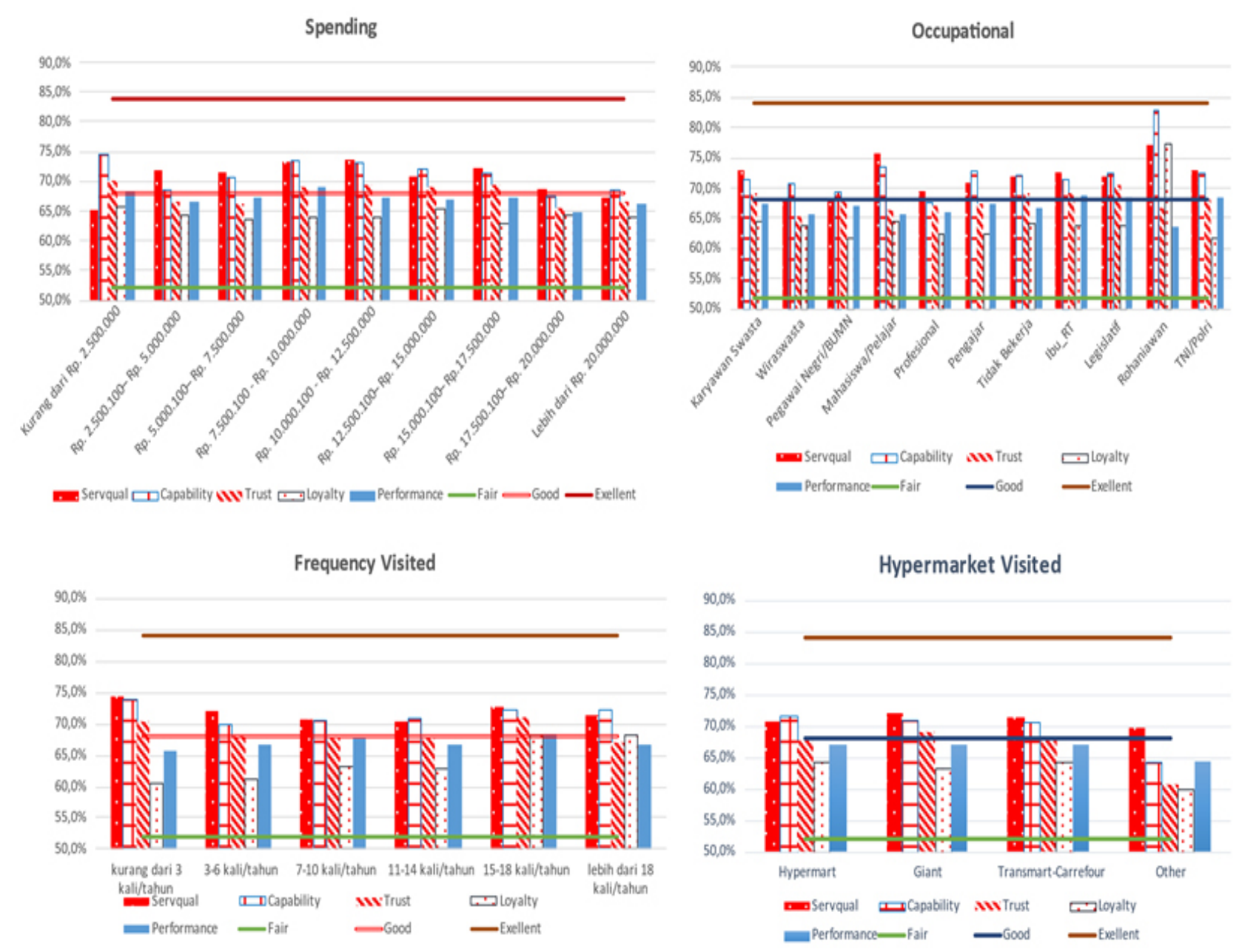

Figure 5. Variabel and activity respondent

Quality of Service in terms of demographic aspects shows that in general the quality of service is perceived as good. It's just that customers with doctoral/doctoral education assess the quality of service in sufficient condition, as well as customers with expenses below Rp2,500.00 and customers of more than Rp20,000,000 assess the quality of the service in sufficient condition. Demographics can serve as an important influence in consumer decisions in the process of purchasing goods and services. In the retail industry, several empirical studies have reported the influence of demographics on customer perceptions and service quality behaviour (Christia and Ard, 2016). Lal et al. (2014) explained that among many demographic variables, it was found that work was a significant factor affecting customer perceptions of overall service quality. Safakli (2007) found that service quality perceptions differ among customers from different occupational groups. It has been proven that people who buy products and services match the work or income they earn. Knowledge of customer work can assist retail business entrepreneurs in devising strategies that are able to provide services more effectively for the specific needs of customers who belong to different job groups; Organizational capabilities are in good condition (71\%). Standard ability $(71.67 \%)$ and dynamic ability (71.71\%) are in good condition, and creative ability is in good condition $(69.64 \%)$ but in good condition is low, or the threshold leads to moderate. In general, the organizational capabilities seen from various aspects of the population are in good condition. However, for customers who live in the Jabodetabek area, customers with an expenditure of Rp17,500,100-Rp20,000.00 and professional jobs, they assess the capabilities of the organization in moderate condition. Research by Fernandez et al. (2014) explain that the demographics and environment of a population are largely responsible for changing the strategies adopted by companies, as well as formulating and implementing strategic changes to increase capabilities and improve organizational performance. This shows that there are efforts needed by the company to improve organizational capabilities or to realize organizational capabilities to customers with criteria that provide a moderate assessment. 
Consumer trust in moderate condition (67.98\%) and is even at the threshold towards good criteria. The dimensions of staff capability are moderate $(67.40 \%)$, virtue $(68.89 \%)$ and integrity $(68.89 \%)$ are borderline good and moderate. Customer trust which is assessed from the overall demographic aspect shows a balance in value, between those who give moderate scores and good scores. Customers who rated good criteria are; Male gender, high school education and S1, married and widowed/widowed, private employees, unemployed, housewives, members of the legislature and Military/ Police give good confidence in the hypermarket. Meanwhile, on the other side, those that provide moderate values are; occupational as an entrepreneur, government staff/state-employee company, student/ student, professional, teacher, spiritualist with an age range of 35-45, 46-55 years. Age 35 and over needs attention because that age has good purchasing power and finances. Moderate conditions must be company's attention so that it can be improved. Adekiya and Adepoju (2016) conducted research on telecommunications companies with the theme of the relationship between brand trust and customer loyalty seen from the influence of the demographic characteristics of respondents. The results showed that the respondent's age group was a significant moderator in the relationship between customer trust and loyalty. The cost of customers who need more attention in order to have a better price is Rp17,000,000-20,000,000 and Rp20,000,000 and above because they show low or moderate confidence such as; customers with a shopping frequency of 7-10/year, 11-14 / year and more than 18 times as well as customers who visit Hypermart and Transmart-carrefour. This customer trust needs to be increased to make it better, with increased trust, the frequency of shopping and loyalty from the re-buying aspect will also increase. The company must provide better trust to customers so that the trust value of ability and virtue can increase and maintain good integrity.

Customer Loyalty is at a moderate level (63.93\%). Repurchasing (68.91\%) and willingness to tell positive things about hypermarkets $(68.42 \%)$ are in low good condition, but borderline to moderate. The dimensions assessed as moderate are; recommending (67.91\%), buying product and service lines $(62.82 \%)$, resistance to the pull of competitors in moderate conditions $(62.39 \%)$, switching to e-commerce $(59.82 \%)$ and attractiveness minimarket $(57.76 \%)$. This shows that hypermarket customer loyalty is not strong easily attracted to competitors, repeat purchases and "word of mouth" promotions are in a critical condition and the transition from good to moderate. All demographic aspects stated moderate criteria, they were customers such as gender, age, education, marital status, city of residence, expenditure, number of visits to hypermarkets visited, all of which were moderate criteria. However, there are some who give good ratings as follows; customers who live in Eastern Indonesia, have high school education, have good loyalty, as well as work as spiritualists, customers with an age range over 65 years show good loyalty. Customers with a frequency of 15-18 times/ year and over 18 times/year also show good loyalty and need to be maintained, but their number is small or a minority who express good loyalty, such as East Indonesia is only $5.9 \%$, the age range is over 65 years old. only $1.6 \%$ of the total population. Deka (2016) changes in demographics, changes in consumer tastes and preferences, e-commerce, and new store formats. to accommodate customers with different tastes and preferences, retailers with newer service ways are entering the market rapidly. The retail market is now a red ocean market and the need for retailers to innovate and create differentiation is indispensable. Several factors have been shown to influence customer loyalty, including perceptions of store attributes, satisfaction, and demographic characteristics. Customer loyalty is the most important factor in building retail success. Loyalty is thought to result in increased profits through increased revenue and reduced costs for acquiring customers and serving them with high quality service. Companies must increase customer loyalty that is being good and retain customers who already have good loyalty.

The performance of hypermarket retail organizations is assessed by customers in moderate conditions (67.05\%), operational performance is considered good $(68.66 \%)$ but in a transitional condition or borderline to moderate. Marketing performance $(64.68 \%)$ is in moderate condition. The marketing performance that is expected to boost retail performance has not been able to improve the performance of hypermarket retail format in Indonesia. Overall, the performance of this hypermarket retail format is considered by customers to have not shown good or moderate conditions. From various demographic aspects, the company's performance is considered moderate. However, several aspects consider the current condition of the company to be good, they are: customers with high school education, customers who live in Kalimantan and East Indonesia, customers who are housewives, legislative 
and military/police, over 65 years of age, and customers who spend their expenses. they. less than Rp. 2,500,000 and an expense of Rp7,500,100-Rp10,000,000, as well as customers with visits 15-18 times/year. However, customers who give this good rating have a small population so that they do not significantly represent the population. Vallabh and Mhlanga (2015), Ahmed and Kar (2019) describe demographic factors such as age, gender, education, income and experience that have a considerable influence on the performance of retail companies. Companies need to make every effort and pay attention to demographic factors to improve their performance.

The description above provides an overview of the condition of hypermarket retail format in Indonesia, although the service quality and capabilities of hypermarket organizations in Indonesia can be categorized as good by customers, but it is not yet stable because some conditions are still in good condition, which are prone to shift to moderate levels. This condition is not able to raise the company's performance plus the condition of Customer Trust and Loyalty is only at a moderate level, meaning that hypermarket customers in Indonesia have moderate or vulnerable loyalty to competitors.

\section{Implication Managerials}

The data distribution and descriptions of retail conditions in hypermarket format is very beneficial for stakeholders, especially management, marketing, operations and research and development in hypermarkets and investor. The characteristics of this data distribution can be used for managers to determine the segmentation, target and positioning of the hypermarket. Managers can use this data to understand the current condition of the retail hypermarket; Service quality and organizational capabilities are at either low or borderline to moderate levels, customer trust and loyalty are not good or quite moderate. Managers must improve aspects of service quality, organizational capabilities, customer trust and customer trust to a good level. Trust and loyalty is very important in business, because it will lead people to buy back and recommend to others. Hypermarket managers must optimize all existing resources; financial resources, human resources, technological resources, and regulatory resources, to increase customer trust, customer loyalty and company performance. Hypermarket managers must improve aspects that are still at a moderate or bad level to become good. It is necessary to increase the reliability of human resources who have high competence in order to be trusted and meet the demands of customers. Furthermore, the company, based on the results of demographic analysis, can map each region or every demographic aspect to create a marketing strategy. For example, in marketing goods and services, one region must be different from another.

The owners, managers and staff of hypermarket retail companies mustimprove company performance because the condition is very crucial for 5 years to continue to decline, by increasing customer trust and loyalty which is still in a moderate condition, as well as continuing to improve service quality and company capabilities that are still at low good level towards moderate borderline. Increasing these variables in order to be able to adapt to customer demands, business demands and competition with minimarkets and online retail businesses.

\section{CONCLUSIONS AND RECOMMENDATIONS}

\section{Conclusions}

The characteristics of the majority of hypermarket format retail customers in Indonesia are; The majority of them have female gender, with a married marital status, Bachelor/S1 education, age range 46-55 years, live in the Jabodetabek area, work private employees, expenditure of Rp10,000,100-Rp12,500,000, visited the hypermarket an average of 7-10 times and 11-14 times a year and the hypermart stores visited the most were hypermart stores. The hypermarket retail format condition in Indonesia, although the service quality and capabilities of hypermart organizations in Indonesia can be categorized as good by customers, it is not yet stable because some conditions are still in a condition that is prone to shift to moderate conditions. This condition is not able to raise the company's performance plus the condition of Customer Trust and Loyalty is in a moderate condition, meaning that hypermarket customers in Indonesia have moderate or vulnerable loyalty to competitors.

\section{Recommendations}

Company performance requires high effort to return to good performance, so the company must always be dynamic and be able to adapt to the demands of customers and business demands today, where the use 
of technology must be implemented to be efficient and effective. So that research is needed concerning aspects of technology and the company's ability to adapt to business demands, as well as aspects that affect the decline in the performance of the hypermarket format retail business in Indonesia. Retail managers must focus more on learning and efforts to increase customer trust and customer loyalty so that retail business performance can increase. After getting an overview of the current retail business, further research is needed to find the right strategy to increase the hypermarket format retail business.

\section{REFERENCES}

AdekiyaA,Adepoju BA.2016. The relationship between brand trust and customer loyalty: The moderating impact of demographic characteristics abstract. International Journal of Marketing Practices 1(1):1-23.

Ahmed YA, Kar B. 2019. Influence of demographic factors on business performance in Ethiopia. International Journal of Innovative Technology and Exploring Engineering 8(12):2875-2862. https://doi.org/10.35940/ijitee.L3034.1081219

Alkhurshan M, Rjoub H. 2020. The scope of an integrated analysis of trust switching barriers, customer satisfaction and loyalty. Journal of Competitiveness 12(2):5-21. Http://dx.doi. org/10.7441/joc.2020.02.01

Armstrong M. 2009. Armstrong's Handbook of Performance Management: An Evidence-based Guide to Delivering High Performance. London: Kogan Page Publishers.

Armstrong M, Baron A. 2002. Strategic HRM, The Key to Improved Business Performance. London: Chartered Institute of Peronnel and Development.

Babelyte LK, Nedzinskas S. 2017. Dynamic capabilities and their impact on research organizations' R\&D and innovation performance. Journal of Modelling in Management 12(4):603-630. Http://dx.doi.org/10.1108/JM2-05-2015-0025

Carmichael G.A. 2016. Fundamentals of Demographic Analysis: Concepts, measurement, Measures and Method. Switzerland: Springer International Publishing. https://doi.org/10.1007/978-3-31923255-3

Christia J, Aaron A. 2016. The influence of demographic characteristics on service quality perceptions.
Journal of Marketing Management 4(2):57-62. https://doi.org/10.15640/jmm.v4n2a5

Christia J, Ard A. 2016. The influence of demographic characteristics on service quality perceptions. Journal of Marketing Management 4(2):57-62. https://doi.org/10.15640/jmm.v4n2a5

Collis DJ. 1994. Research note: how valuable are organizational capability. Strategy Management Journal 15(8):143-152. https://doi.org/10.1002/ smj.4250150910

Deka PK. 2016. Understanding customer loyalty for retail stores and the influencing factors. Journal of Management in Practice 1(1):1-14.

Fernandez MCD, Rodríguez MRG, Simonetti B. 2014. Top Management Teams' demographic characteristics and their influence on strategic change. Journal of Business Research 5(5):7583.

Griffin R, Moorhead W, Gregory. 2014. Organizational Behavior: Managing People and Organizations. 11th Ed. Kentucky: McGraw-Hill.

Kennedy DM, Anastos CT, Genau MC. 2019 Improving healthcare service quality through performance management. Leadership in Health Services 32(3):477-492. Http://dx.doi.org/10.1108/LHS02-2019-0006

Kotler P, Keller KL. 2016. Marketing Management. 16th Ed. New Jersey: Pearson Pretice Hall Published.

Lal J, Vij M, Jain S. 2014. Do demographics influence customer service quality perceptions? A comparative study of Indian and foreign banks. Journal of Services Research 14(2):75-105.

Mayer RC, Schoorman FD, Davis JH. 2007. An integrative model of organizational trust: past, present, and future. Academy of Management Review 32(2):344-354. https://doi.org/10.5465/ amr.2007.24348410

Mehta AM, Tariq M. 2020. How brand image and perceived service quality affect customer loyalty through customer satisfaction. Academy of Marketing Studies Journal 24(1):1-10.

Murdock SH, Kelley C, Jordan J, Pecotte B, Luedke A. 2006. Demographics: A Guide to Methods and Data Sources for Media, Business, and Government. New York: Routledge.

Rajapathirana RJ, Hui Y. 2018. Relationship between innovation capabilities, innovation type, and firm performance. Journal of Innovation \& Knowledge 3(1):44-55.https://doi.org/10.1016/j. jik.2017.06.002 
Rampl LV, Eberhardt T, Schutte R, and Kenning P. 2012. Consumer trust in food ritelers: conceptual framework and empirical evidence. International Journal of Ritel and Distribution Management 40(4):254-272. https://doi. org/10.1108/09590551211211765

Safakli O. 2007. Credit risk assessment for the banking sector of Northern Cyprus. Journal of Yasar University 615-630.

Siegel JS, SwansonDA. 2004. The Methods and Materials of Demography. 2nd Ed. London: Elsevier Academic Press.
Vallabh D, Mhlanga O. 2015. Influence of demographic factors on business performance in small to medium tourism enterprises (SMTEs). African Journal of Hospitality, Tourism and Leisure 4(2):1-9.

Westland JC. 2019. Structural Equation Models: From Paths to Networks, S2nd Ed. Switzerland:pringer Nature. $\quad$ https://doi.org/10.1007/978-3-03012508-0

Zeithaml VA, Parasuraman, and Berry. 2002. Delivering Service Quality. New York: Mc Milan. 